\title{
Structural Effects on the Formation of Proton and Alkali Metal Ion Adducts of Apolar, Neutral Peptides: Electrospray Ionization Mass Spectrometry and Ab Initio Theoretical Studies
}

\author{
R. Sudha, ${ }^{[a]}$ M. Panda, ${ }^{[b]}$ J. Chandrasekhar, ${ }^{*[b]}$ and Padmanabhan Balaram*[a]
}

\begin{abstract}
Apolar, neutral peptides have been shown to ionize extremely well under the conditions used for electrospray ionization mass spectrometry (ESIMS). Peptides for which the conformations have been independently determined in solution and in crystals have been examined by ESIMS. Studies of peptide helices ranging from 7 to 18 residues reveal that shorter helices yield exclusively singly charged ions, while in larger helices multiply charged species are detectable. Multiple sites for protonation/metallation are introduced in the
\end{abstract}

helix by proline insertion or by changing the chirality in the residue. The preferred site of cation binding to helices may be the C-terminus end, where three free $\mathrm{C}=\mathrm{O}$ groups are available for chelation. Ab initio and DFT calculations at several levels have been carried out for the binding of $\mathrm{H}^{+}, \mathrm{Li}^{+}, \mathrm{Na}^{+}$, and $\mathrm{K}^{+}$to $\left.\mathrm{CHO}-(\mathrm{Gly})_{3}\right)$-OMe. The results reveal that metallation in helices is favoured by

Keywords: mass spectrometry metalation $\cdot$ peptides $\cdot$ protonation chelation to carbonyl groups at the C-terminus, while protonation involved two carbonyl groups and thus favour a 10-membered cyclic hydrogen-bonded structure. In $\beta$-strands, metallation/protonation occurs at isolated carbonyl groups. Collision induced fragmentation of hydrophobic peptides under ESI conditions reveals that helix fragmentation occurs predominantly from the C-terminus, while in $\beta$-hairpins cleavage occurs simultaneously at multiple sites.

\section{Introduction}

The recent developments in soft ionization procedures, electrospray and matrix assisted laser desorption (MALDI) for the formation of macromolecular ions, has made the molecular weight determination in the high mass range routine. ${ }^{[1]}$ Ionization of macromolecules is achieved by protonation to form a positively charged species $[M+n \mathrm{H}]^{n+}$ or by deprotonation to a negatively charged species $[M-n \mathrm{H}]^{n-}$. Proteins usually exhibit a coherent series of multiply charged ions under electrospray ionization conditions, from which the molecular mass of the protein is calculated. The number of charges observed in the ESI mass spectra of proteins is sensitive to the changes in the $\mathrm{pH}$ of the solution. ${ }^{[2]}$ Several reports in the literature suggest that conformational properties of biomolecules in solution are preserved during the ionization process and persist over the transient time that ions exist in mass spectrometers. ${ }^{[3]}$ In the case of peptides, the maximum number of charges observed generally correlates with the number of residues with basic or acidic side chains. In

[a] Prof. P. Balaram, R. Sudha Molecular Biophysics Unit and Department of Organic Chemistry

Indian Institute of Science, Bangalore 560012 (India) Fax: (91)80-3600683 or -3600535

[b] J. Chandrasekhar, M. Panda

Department of Organic Chemistry

Indian Institute of Science

Bangalore 560012 (India) the electrospray ionization mass spectra (ESIMS) of polypeptides, along with the proton adducts, sodium and potassium adducts are also often observed under the electrospray ionization conditions. ${ }^{[4]}$ Apart from the determination of molecular weight of macromolecules, mass spectrometry has been used for studies on noncovalent macromolecule-ligand interactions. ${ }^{[5]}$ Liquid chromatography interfaced with electrospray ionization mass spectrometry (LC/ESIMS) and tandem mass spectrometry (MS/MS) have been used for the analysis of complex mixtures of peptides obtained in the enzymatic cleavage of proteins. ${ }^{[6]}$

Currently mass spectrometry is extensively used for structural investigations of peptides and proteins in the gas phase. Methods based on measurement of size such as ion mobility measurements to determine the collision cross sections, chemical methods such as H/D exchange have been used for the structural studies. ${ }^{[7]}$ Deuterium labeling studies suggest that fast intramolecular proton transfers yield a rapidly interconverting population of structures and induce charge directed fragmentation after gas phase collisional activation. ${ }^{[8]}$

However, most reports on electrospray ionization mass spectrometry are on the analysis of hydrophilic substrates. Mass spectrometric analysis of hydrophobic species such as membrane proteins or transmembrane peptides has seldom been reported in the literature. ${ }^{[9]}$ This is mainly due to the presence of salts and detergents used to solubilize the hydrophobic proteins and peptides, which suppress the analyte ion formation. ${ }^{[10]}$ Furthermore, hydrophobic proteins 
and peptides are usually not soluble in aqueous solvent used for ESIMS. In the present study, we report the analysis of hydrophobic peptides (which are freely soluble in a variety of organic solvents) under electrospray ionization conditions using methanol as the solvent. During the mass spectrometric analysis of hydrophobic peptides using ESIMS, we observed intense peaks corresponding to the proton/alkali metal ion adducts of the peptides. To understand the effect of chain length and structure of the peptides on the adduct formation, a systematic study was carried out using hydrophobic peptides of varying lengths and conformations. The peptides used in this study are de novo designed peptides with defined secondary structures (helices and hairpins) in the solution and solid state. ${ }^{[11]}$ The role of secondary structures on the protonation/metallation and fragmentation of hydrophobic peptides has been probed using ESIMS.

While the development of new techniques in mass spectrometry has helped to estimate the cation binding affinities of peptides, theoretical calculations have been shown to be valuable in providing insights into the observed ligand-metal ion specificities with the added advantage of quantitative prediction of structural and energetic changes. ${ }^{[12]}$ Detailed geometrical analyses as well as quantitative estimation of the cation binding affinities of model peptides in different conformations have been carried out by Hartree-Fock, MP2 and hybrid HF-DFT calculations. The results are used to interpret ESI mass spectral data of cation complexes of the peptides. The analysis of the geometry and energetics of complexes sheds light on some general features of the conformational dependence of cation binding affinity of peptides.

\section{Results and Discussion}

Mass spectrometric studies: Table 1 shows the sequence, structures of the peptides determined by NMR and crystallo- graphic techniques ${ }^{[13-25]}$ and the peaks observed in the electrospray ionization mass spectra of the peptides used in this study, which range in length from 6 to 18 residues. Though the mass spectra were recorded using methanol as the solvent, sodium and potassium adducts were observed along with proton adducts. This is presumably due to complexation with trace alkali metal ions during the sample preparation and the electrospray process, which brings the peptide solution in contact with a glass capillary. Under these conditions protonated species generally predominate. In the ESI mass spectra of smaller peptides with fewer than 10 residues $(\mathbf{1}-\mathbf{5}, \mathbf{1 7}-\mathbf{1 9})$, only molecular ion peaks $[M+\mathrm{H}]^{+},[M+\mathrm{Na}]^{+},[M+\mathrm{K}]^{+}$and no multiply charged species are observed. ESI mass spectra of peptides with $10-12$ residues $(\mathbf{6}-\mathbf{9})$ show peaks corresponding to both singly charged and doubly charged species with molecular ion peak as the major species. In peptides with more than 14 residues $(\mathbf{1 1}, \mathbf{1 2}, \mathbf{1 4}, \mathbf{1 5})$, the intensity of the peak corresponding to the doubly charged species was observed to be greater than the molecular ion peak. ESI mass spectra of peptides 10, 13 and 16 show only the doubly charged species and no molecular ion peaks were observed.

Figure 1 compares the ESI mass spectra of helical peptides of varying lengths, a 7-residue helical peptide (3), a 12-residue helical peptide (9) and a 16-residue helical peptide (12). The ESI mass spectrum of peptide $\mathbf{3}$ shows only the molecular ion peaks at $m / z, 784[M+\mathrm{H}]^{+}, 806[M+\mathrm{Na}]^{+}$; no doubly charged species is observed. The spectrum of peptide 9 has both a molecular ion peak at $m / z, 1210[M+\mathrm{H}]^{+}$and a doubly charged species at $m / z 605[M+2 \mathrm{H}]^{2+}$ of approximately equal intensity; the spectrum of peptide $\mathbf{1 2}$ has a molecular ion peak at $m / z, 1605[M+\mathrm{H}]^{+}$and a doubly charged species at $\mathrm{m} / z .803$ $[M+2 \mathrm{H}]^{2+}$, which is the major species.

These results indicate that the increase in the number of residues favours the formation of multiply charged species. Ionisation of the hydrophobic peptides takes place through binding of a proton or a metal ion to the basic sites in the

Table 1. Summary of mass spectral and conformational properties of peptides. ${ }^{[a]}$

\begin{tabular}{|c|c|c|c|c|c|c|c|}
\hline Sequence & & Cal.Wt. & $\begin{array}{l}\text { Peaks } \\
\text { observed }\end{array}$ & Species present & $\begin{array}{l}\text { No. of } \\
\text { residues }\end{array}$ & $\begin{array}{l}\text { Solution/ } \\
\text { X-ray structure }\end{array}$ & $\mathrm{Re}$ \\
\hline Boc-FUVALF-OMe & 1 & 794 & $795,817,833$ & {$[M+\mathrm{H}]^{+}[M+\mathrm{Na}]^{+}[M+\mathrm{K}]^{+}$} & 6 & helix & [b] \\
\hline Boc- $\mathrm{V}_{2} \mathrm{UPV}_{3}-\mathrm{OMe}$ & 2 & 809 & $810,832,848$ & {$[M+\mathrm{H}]^{+}[M+\mathrm{Na}]^{+}[M+\mathrm{K}]^{+}$} & 7 & helix & [13] \\
\hline Boc-VALUVAL-OMe & 3 & 783 & 784,806 & {$[M+\mathrm{H}]^{+}[M+\mathrm{Na}]^{+}$} & 7 & helix & [14] \\
\hline Boc-VALFVAL-OMe & 4 & 845 & $846,868,884$ & {$[M+\mathrm{H}]^{+}[M+\mathrm{Na}]^{+}[M+\mathrm{K}]^{+}$} & 7 & extended & [b] \\
\hline Boc- $[\mathrm{ALU}]_{3}-\mathrm{OMe}$ & 5 & 939 & $940,962,978$ & {$[M+\mathrm{H}]^{+}[M+\mathrm{Na}]^{+}[M+\mathrm{K}]^{+}$} & 9 & helix & [15] \\
\hline Boc-U[ALU $]_{3}-\mathrm{OMe}$ & 6 & 1024 & $1025,513,524$ & {$[M+\mathrm{H}]^{+}[M+2 \mathrm{H}]^{2+}[M+\mathrm{H}+\mathrm{Na}]^{2+}$} & 10 & Helix & [16] \\
\hline Boc-LGp[VALU] $]_{2}-\mathrm{OMe}$ & 7 & 1136 & $1137,569,580$ & {$[M+\mathrm{H}]^{+}[M+2 \mathrm{H}]^{2+}[M+\mathrm{H}+\mathrm{Na}]^{2+}$} & 11 & [c] & [b] \\
\hline Boc-VALUVALUVAL-OMe & 8 & 1152 & $1153,577,588$ & {$[M+\mathrm{H}]^{+}[M+2 \mathrm{H}]^{2+}[M+\mathrm{H}+\mathrm{Na}]^{2+}$} & 11 & helix & [b] \\
\hline Boc- $[\mathrm{ALU}]_{4}-\mathrm{OMe}$ & 9 & 1209 & $1210,605,616$ & {$[M+\mathrm{H}]^{+}[M+2 \mathrm{H}]^{2+}[M+\mathrm{H}+\mathrm{Na}]^{2+}$} & 12 & helix & [17] \\
\hline Boc-L-[VALUVAL]-D-[VALUVAL]-OMe & 10 & 1135 & $718.8,729.8$ & {$[M+2 \mathrm{H}]^{2+}[M+\mathrm{H}+\mathrm{Na}]^{2+}$ No molecular ion peak } & 14 & broken helix & {$[18]$} \\
\hline Boc-UV $-V_{7}-\beta-A l a-U V_{7}-O M e$ & 11 & 1505 & $1507,754,765$ & {$[M+\mathrm{H}]^{+}[M+2 \mathrm{H}]^{2+}[M+\mathrm{H}+\mathrm{Na}]^{2+}$} & 15 & [c] & [b] \\
\hline Boc-[VALU] $]_{4}-\mathrm{OMe}$ & 12 & 1604 & $1605,803,814$ & {$[M+\mathrm{H}]^{+}[M+2 \mathrm{H}]^{2+}[M+\mathrm{H}+\mathrm{Na}]^{2+}$} & 16 & helix & [19] \\
\hline Boc-UV - -Acp-Acp-UV - -OMe & 13 & 1660 & 831,842 & {$[M+2 \mathrm{H}]^{2+}[M+\mathrm{H}+\mathrm{Na}]^{2+}$ No molecular ion peak } & 16 & broken helix & [20] \\
\hline antiameobin & 14 & 1656 & $1657,829,840$ & {$[M+\mathrm{H}]^{+}[M+2 \mathrm{H}]^{2+}[M+\mathrm{H}+\mathrm{Na}]^{2+}$} & 16 & helix & [21] \\
\hline zervamicin & 15 & 1839 & $1840,920,614$ & {$[M+\mathrm{H}]^{+}[M+2 \mathrm{H}]^{2+}[M+3 \mathrm{H}]^{3+}$} & 16 & bent helix & [22] \\
\hline Boc-UVALUVALGp(VALU) $)_{2}$-OMe & 16 & 1758 & 880,891 & {$[M+2 \mathrm{H}]^{2+}[M+\mathrm{H}+\mathrm{Na}]^{2+}$ No molecular ion peak } & 18 & broken helix & [b] \\
\hline Boc-LVVpALVV-OMe & 17 & 923 & 924,946 & {$[M+\mathrm{H}]^{+}[M+\mathrm{Na}]^{+}[M+\mathrm{K}]^{+}$} & 8 & $\beta$-hairpin & [23] \\
\hline Boc-LFVpGLFV-OMe & 18 & 1006 & 1007,1029 & {$[M+\mathrm{H}]^{+}[M+\mathrm{Na}]^{+}[M+\mathrm{K}]^{+}$} & 8 & $\beta$-hairpin & [24] \\
\hline Boc-LVVpGLFV-OMe & 19 & 957 & 958,980 & {$[M+\mathrm{H}]^{+}[M+\mathrm{Na}]^{+}[M+\mathrm{K}]^{+}$} & 8 & $\beta$-hairpin & [25] \\
\hline
\end{tabular}

[a] $\mathrm{U}=\alpha$ Aminoisobutyric acid. (Aib). [b] Unpublished. [c] Conformation not established unambiguously but contains large helical segment. Antiameobin: Ac-Phe-Aib-Aib-Aib-Iva-Gly-Leu-Aib-Aib-Hyp-Gln-Iva-Hyp-Aib-Pro-Ph-OH. Zervamicin: Ac-Leu-Ile-Gln-Iva-Ile-Thr-Aib-Leu-Aib-Hyp-Gln-AibHyp-Aib-Pro-Ph-OH. 

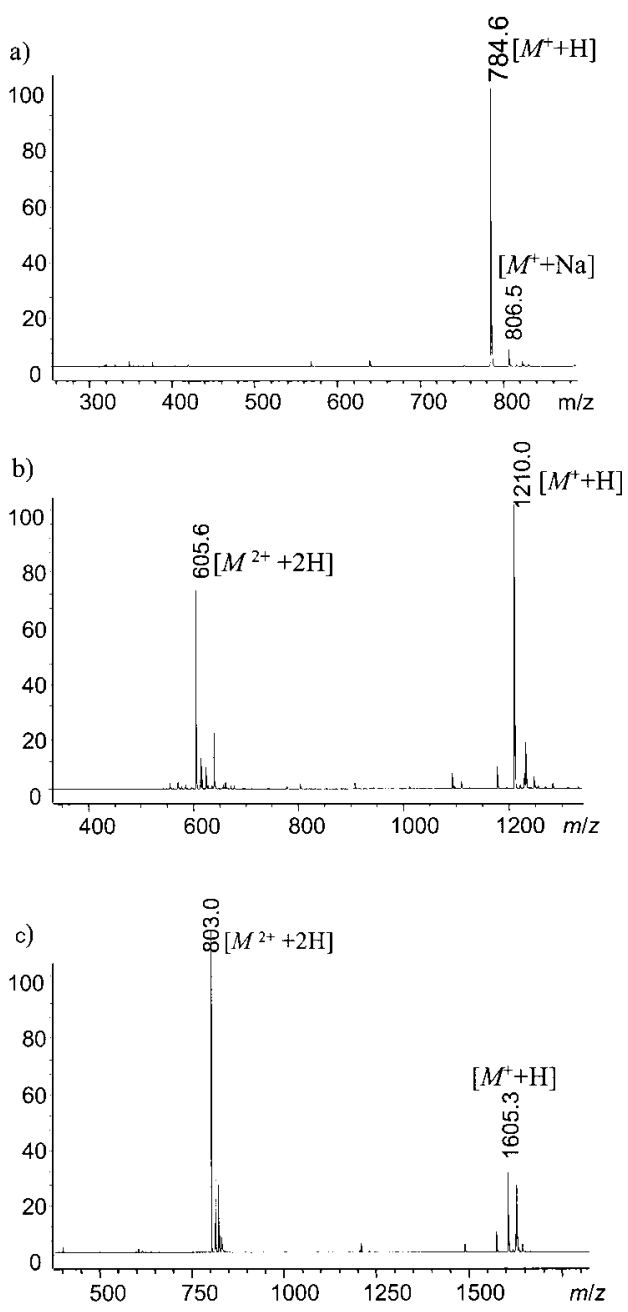

Figure 1. ESI mass spectra of a) peptide $\mathbf{3}, \mathrm{b}$ ) peptide $\mathbf{9}$, and c) peptide $\mathbf{1 2}$ recorded in methanol at skimmer potential $20 \mathrm{~V}$.

peptide, which in the case of fully protected hydrophobic peptides studied here are limited to the amide bonds. In the literature, experiments on the small oligoalanine and oligoglycine peptides suggest that in peptides composed only of nonbasic residues the proton may be solvated completely by the various amide oxygens. ${ }^{[26,27]}$ Chakrabarti has reported from a Protein Data Bank analysis that metal ions, predominantly $\mathrm{Ca}^{2+}$, bind to the amide carbonyls at the $\mathrm{C}$-terminus as a multidentate ligand in helical structures and on the peripheral strands and at the sides of the strands in $\beta$ sheets. ${ }^{[28]}$ In hairpin structures the metal binding could be localized on a single carbonyl group at the terminus or near the turn region (Figure $2 \mathrm{a}$ ). In peptides where the structure is a continuous helix, there are three carbonyl groups at the C-terminus that are not involved in intramolecular hydrogen bonding. The orientation of these carbonyl groups favors chelation of metal ions (Figure $2 \mathrm{~b}$ ). Also, the dipole orientation in helical peptides favors protonation/metallation at the C-terminus. Polypeptide helices possess a significant macrodipole in which the $\mathrm{C}$-terminus is the negative end. ${ }^{[29]}$ The observation of multiply charged species in longer helices may be indicative of backbone protonation/metallation at sites

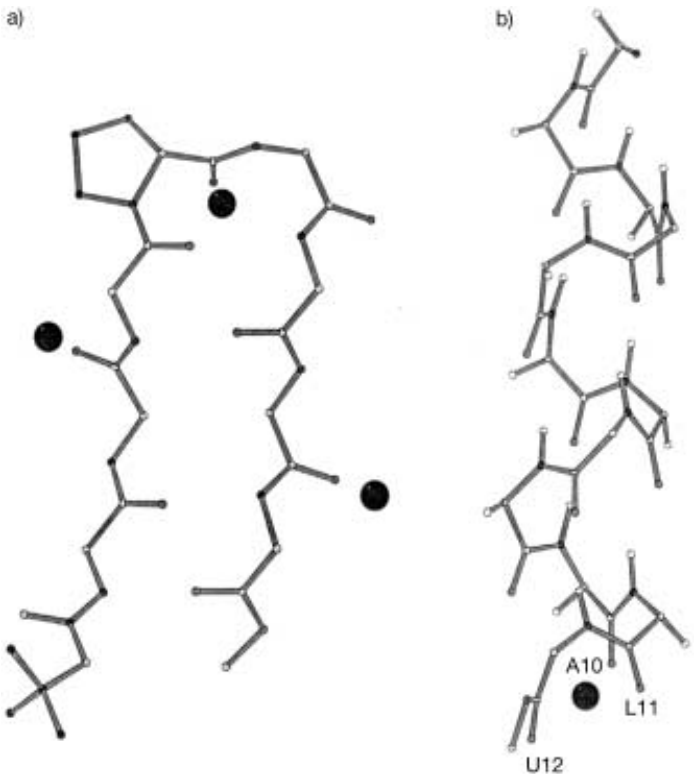

Figure 2. Schematic representation of cation binding to a) hairpin and b) helical peptides.

distant from the $\mathrm{C}$-terminus, such that electrostatic repulsions are minimised. In order to further probe the structural requirement for multiply charged ion formation, we investigated a set of well characterized peptides containing interrupted helical segments which will result in centrally located free carbonyl units for metallation/protonation.

Figure 3 a shows the mass spectrum of a 14 residue helical peptide (10) containing mixed chiral blocks. This "ambidextrous" molecule has two helical segments of opposite screw sense fused together in the same molecule. At the site of chiral reversal, the carbonyl groups of residue 6 is not involved in intramolecular hydrogen bonding and it can be a potential protonation/metallation site. ${ }^{[18]}$ Figure $3 \mathrm{~b}$ shows the mass spectrum of zervamicin (15), which has a bent helical structure due to the presence of three Pro/Hyp residues at the C-terminus. ${ }^{[22]}$ Figure $3 \mathrm{c}$ shows the spectrum of an 18 residue helical peptide $\mathbf{1 6}$ containing two helical segments linked using a -Gly-D-Pro- unit. Though peptide $\mathbf{1 0}$ has only 14 residues, the spectrum shows the presence of only doubly charged species at $\mathrm{m} / \mathrm{z} 718$ and 729 , corresponding to $[M+2 \mathrm{H}]^{2+}$ and $[M+\mathrm{H}+\mathrm{Na}]^{2+}$. The molecular ion peak is not observed. Similarly, in the ESI spectra of peptide 13 (two helical segments are linked by Acp units) and peptide $\mathbf{1 6}$ which have a centrally located distortion in the helical structure, only the doubly charged species is detected and no molecular ion peak is observed. The spectrum of zervamicin (15) shows the presence of singly, doubly and triply charged species at $m / z 1840,920$ and 614, respectively, with the doubly charged ion as the major species. These results indicate that discontinuities in the helical structures favour protonation/metallation at additional sites, which could arise from the presence of exposed carbonyl groups that are not involved in intramolecular hydrogen bonding. To understand the preferences of cation binding sites in helical and hairpin peptides, theoretical calculations were carried out in model systems. 

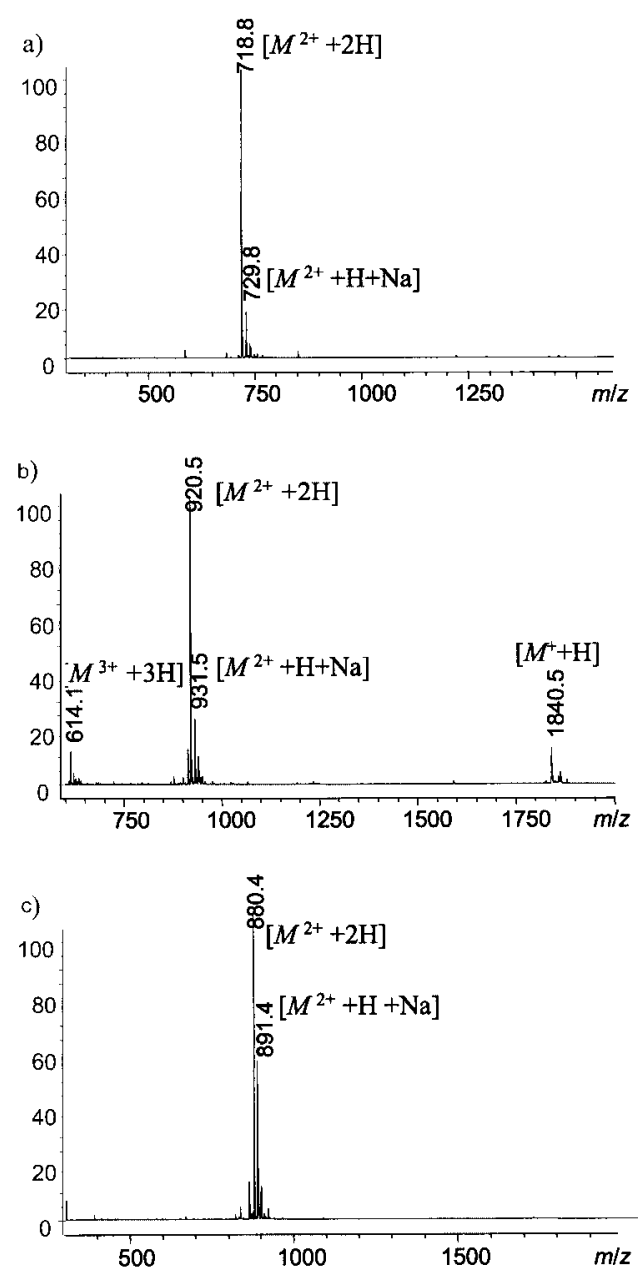

Figure 3. ESI mass spectra of a) peptide $\mathbf{1 0}, \mathrm{b}$ ) peptide $\mathbf{1 5}$, and c) peptide 16 recorded in methanol at skimmer potential $20 \mathrm{~V}$.

Ab initio studies of metallation/protonation: In order to simplify the model systems chosen for the theoretical analysis we limit our investigations to the study of $\mathrm{N}$-formyltriglycyl methyl ester [CHO- $\left.(\mathrm{Gly})_{3}-\mathrm{OCH}_{3}\right]$-cation complexes (Scheme 1). In this system the presence of three glycines allows the formation of an intramolecular hydrogen bond between the N-H group of the Gly(3) and the formyl oxygen in an ideal $3_{10^{-}}$helical conformation. For this study, the $3_{10^{-}}$ helix, which occurs frequently in this class of hydrophobic peptides, ${ }^{[30]}$ is taken as representative of the more general
$\mathrm{Gly}_{3}$

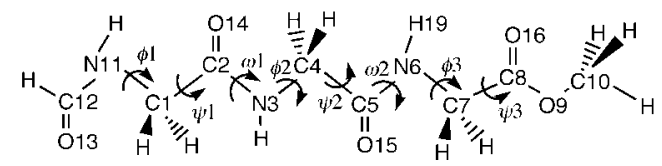

Gly

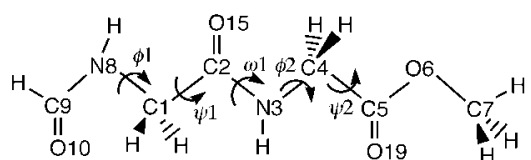

Scheme 1. The model systems used for the calculations of cation binding to peptides. class of peptide helices which are included in protein $\alpha$ helices. We studied the structure and binding energies of $\mathrm{Li}^{+}$, $\mathrm{Na}^{+}$and $\mathrm{K}^{+}$complexes of $\mathrm{Gly}_{3}$ in two different conformations, the $3_{10}$-helical and $\beta$-sheet conformations. In addition, some calculations were also carried out with $\mathrm{N}$-formyldiglycyl methyl ester [CHO-(Gly $)_{2}-\mathrm{OCH}_{3}\left(\mathrm{Gly}_{2}\right.$, Scheme 1)] to evaluate specific features in the single type III $\beta$-turn ${ }^{[31]}$ which is a repetitive feature of the $3_{10}$-helix.

Full optimizations of the free peptide starting from the ideal torsional values of helical peptides results in minima corresponding to non-helical conformations. Previous ab initio calculations also indicate that helical structures for Gly and Ala dipeptides do not correspond to stable minima. ${ }^{[32]}$ Hence, we have chosen ideal backbone torsional angles that could lead to the specific conformations and optimized all other degrees of freedom. The $(\phi, \psi, \omega)$ constraints imposed are $\left(-60^{\circ},-30^{\circ}, 180^{\circ}\right)$ and $\left(-120^{\circ}, 120^{\circ}, 180^{\circ}\right)$, respectively, for $3_{10}$-helical and $\beta$-strand peptides both in the free and complexed form. The binding energies obtained with these geometries, in which a set of dihedral angles are held at idealized values, are referred to as POPT data. Since geometric reorganization and the consequent energy gain are expected to be greater in the complexed form, the POPT binding affinities are likely to be underestimated. We have also carried out full optimization of the complexes taking the aforementioned partially optimized structures as initial guesses and lifting the constraints. To compute the binding energies of these fully optimized complexes, the single point energies of the free peptide at their respective complex geometries (FOPT) were used. The energies of the bound species corresponded to those of fully optimized geometries where as the energies for the free peptide were taken from a single point calculation taking the corresponding geometry of the bound complex without the metal ion or proton. As a result the electronic energy of the complex at a particular level of theory is more accurately described compared with the free peptide. Thus, the interaction energy is overestimated. The energies from fully optimized free peptide would have been ideal, but it leads to a non-helical conformation. Therefore we computed the interaction energies for the fully optimized complexes (FOPT). Even though the absolute interaction energies were overestimated, the overall trend of interaction energies, we are interested in, would be unchanged.

The premise on which the theoretical calculations are based is that, in a peptide helix, the three carbonyl groups at the C-terminus point approximately in the same direction; this suggests chelation of cations as an attractive possibility. The cation was therefore placed symmetrically with respect to the three coordinating carbonyl groups in the initially assumed structure. Preliminary studies revealed that the energy minima corresponding to proton adducts were heterogeneous. These minima corresponded to structures in which one of the carbonyl groups is no longer coordinated, in contrast to the binding of the alkali metal ions. We will therefore first describe the results of the ab initio calculations of metallation and subsequently turn to protonation.

The cation binding affinities obtained at the HF/6-31G(d) level (Table 2) were generally underestimated whereas the 
Table 2. $\mathrm{Li}^{+}, \mathrm{Na}^{+}$and $\mathrm{K}^{+}$affinities $\left[\mathrm{kcal} \mathrm{mol}^{-1}\right]$ of CHO-(Gly $)_{3}-\mathrm{OCH}_{3}$ in helical and $\beta$-strand conformations.

\begin{tabular}{|c|c|c|c|c|}
\hline \multirow[t]{2}{*}{ Level of theory } & \multicolumn{2}{|c|}{ Helical conformation } & \multicolumn{2}{|c|}{$\beta$-strand conformation } \\
\hline & $\mathrm{POPT}^{[a]}$ & $\mathrm{FOPT}^{[\mathrm{d}]}$ & $\mathrm{POPT}^{[\mathrm{b}]}$ & $\mathrm{POPT}^{[c]}$ \\
\hline \multicolumn{5}{|l|}{$\mathrm{Li}^{+}$affinity } \\
\hline $\mathrm{HF} / 6-31 \mathrm{G}(\mathrm{d}) \mathrm{opt}$ & 81.19 & 113.24 & 54.59 & 52.07 \\
\hline B3LYP/6-31G(d) & 86.83 & 113.52 & 58.06 & 54.44 \\
\hline MP2(full)/6-31G(d) & 89.02 & 111.31 & 56.44 & 52.86 \\
\hline \multicolumn{5}{|l|}{$\mathrm{Na}^{+}$affinity } \\
\hline $\mathrm{HF} / 6-31 \mathrm{G}(\mathrm{d}) \mathrm{opt}$ & 60.53 & 85.48 & 39.27 & 36.63 \\
\hline B3LYP/6-31G(d) & 65.14 & 86.09 & 41.95 & 38.58 \\
\hline MP2(full)/6-31G(d) & 66.47 & 84.53 & 40.94 & 37.37 \\
\hline \multicolumn{5}{|l|}{$\mathrm{K}^{+}$affinity } \\
\hline $\mathrm{HF} / 6-31 \mathrm{G}(\mathrm{d}) \mathrm{opt}$ & 43.15 & 63.28 & 27.99 & 25.36 \\
\hline B3LYP/6-31G(d) & 46.65 & 63.85 & 30.28 & 26.76 \\
\hline MP2(full)/6-31G(d) & 48.76 & 63.88 & 30.09 & 26.75 \\
\hline
\end{tabular}

[a] Partial optimization at fixed dihedral angles $\left(\phi=-60^{\circ} ; \psi=-30^{\circ} ; \omega=\right.$ $180^{\circ} ; 3_{10}$-helical conformation). [b] Partial optimization of $\beta$-strand conformation at fixed dihedral angles $\left(\phi=-120^{\circ} ; \psi=120^{\circ} ; \omega=180^{\circ}\right)$; metallation occurs at the terminal carbonyl oxygen (O13). [c] Partial optimization of $\beta$-strand conformation at fixed dihedral angles $\left(\phi=-120^{\circ}\right.$; $\left.\psi=120^{\circ} ; \omega=180^{\circ}\right)$; metallation occurs at the middle carbonyl oxygen (O15). [d] Full optimization of the complexes taking the POPT structures as initial guess. The energies of the free peptide were computed by a single point calculation taking the fully optimized geometry of the complex without the ions to calculate binding energies (affinities). The affinities are consequently overestimated.

proton affinities were overestimated (Table 3). This is presumably due to the limitation of the basis set and the basis set superposition error (BSSE). However, the B3LYP/6-31G(d) data were comparable to those of MP2(full) calculations. More importantly, identical trends are noted at all the levels of theory (HF, DFT and MP2). Throughout the discussion, the binding affinities obtained from MP2(full)/6-31G(d)//HF/6$31 \mathrm{G}(\mathrm{d})$ method are considered.
Ab initio studies of metallation in $\mathbf{G l y}_{3}$ : The energetics for the binding of $\mathrm{Li}^{+}, \mathrm{Na}^{+}$, and $\mathrm{K}^{+}$to $\mathrm{Gly}_{3}$ in helical and $\beta$-strand conformations are summarized in Table 2 . Partially optimized structures of metal ion complexes of $3_{10}$-helical Gly 3 exhibited tridentate chelation (1a, Figure 4). Clearly the larger size of the metal cations allows them to bind to the multiple basic sites more effectively. The metal ion binds to two amide carbonyl oxygens (O14 and O15) and the methoxy oxygen (O9). The backbone torsional angles and the length of the peptide chain in $\mathrm{Gly}_{3}$ enable it to form an intramolecular hydrogen bond between the carbonyl oxygen of the formyl group and the amide hydrogen of the third glycine unit. The $\mathrm{Li}^{+}, \mathrm{Na}^{+}$and $\mathrm{K}^{+}$binding affinities are 89.0, 66.5 and $48.8 \mathrm{kcal} \mathrm{mol}^{-1}$, respectively. Fully optimized geometries of the complexes of helical peptides retained the intramolecular hydrogen-bonding characteristic of the helical forms. The ester carbonyl group is oriented towards the metal ion and the complex is highly stabilized by optimal tridentate chelation $\left(\mathrm{Gly}_{3}-\mathrm{Li}^{+}: \mathbf{1 b}\right.$, Figure 4). This suggests that the binding of metal ion to the free carbonyl groups of the C-terminus of a long peptide chain is an attractive possibility.

For the $\beta$-strand conformations the metal ion affinities were computed at the formyl carbonyl oxygen (O13) and at one of the internal amide carbonyl oxygen atoms (O15) (1c, 1d, Figure 4). The antiparallel orientation of the carbonyl groups in the nearly linearly arranged sequence of amide groups allows only monodentate chelation at one of the carbonyl oxygen atoms. The $\mathrm{Li}^{+}, \mathrm{Na}^{+}$and $\mathrm{K}^{+}$binding energies are 56.4, 40.9 and $30.1 \mathrm{kcal} \mathrm{mol}^{-1}$, respectively, when the metal ion binds to O13. Complexation with O15 leads to binding energies of $52.9,37.4$ and $26.8 \mathrm{kcal} \mathrm{mol}^{-1}$, respectively. These values are comparable to the interaction energy of a simple amide, $N$-methylacetamide. ${ }^{[33]}$

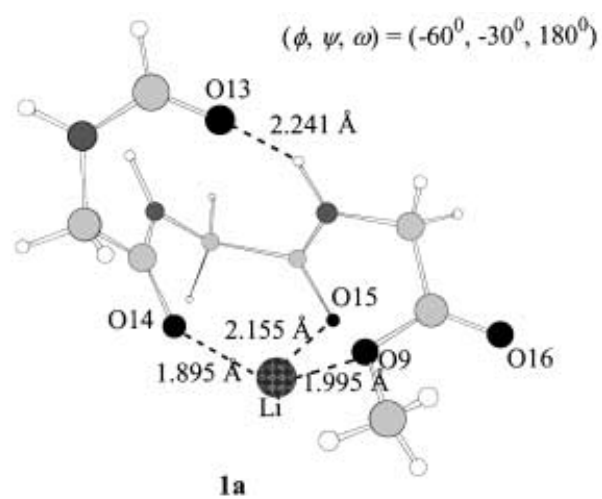

$1 \mathbf{a}$

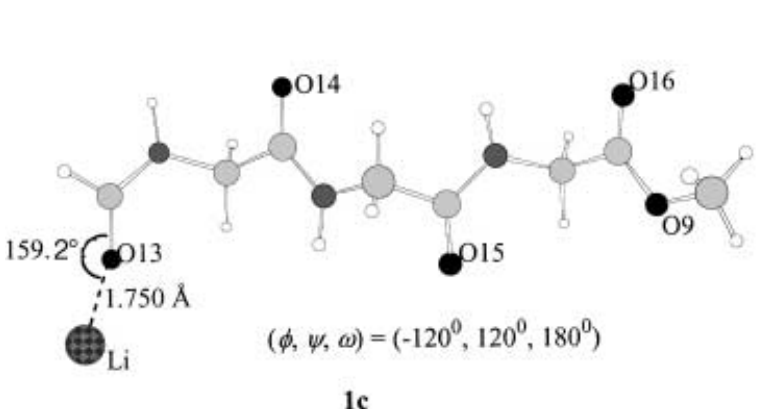

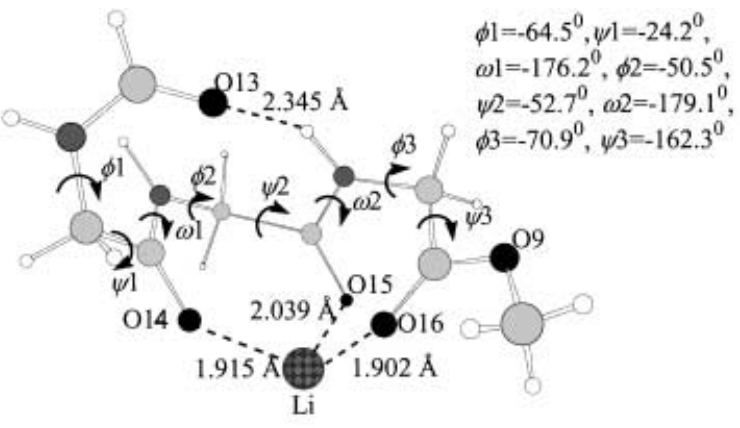

$1 b$

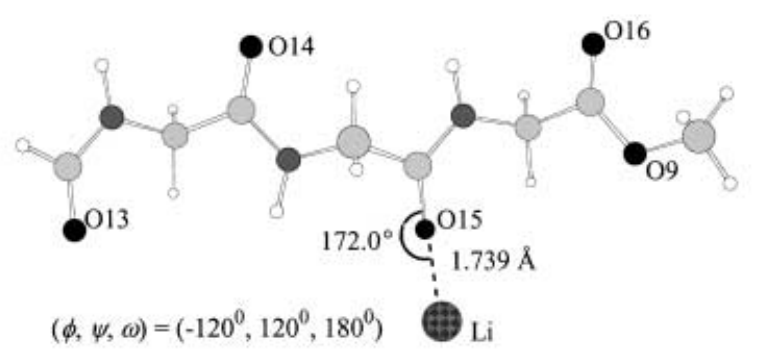

1d

Figure 4. HF/6-31G(d) partially optimized geometries of $\mathrm{Li}^{+}$complex of $\mathrm{Gly}_{3}$ in $3_{10}$-helical (1a), $\beta$-strand (1c and 1d) conformations and fully optimized geometry of helical conformation (1) starting from the helical conformation $\mathbf{1}$ a. 
The validity of the trends in the POPT binding affinities of the $\beta$-strand was confirmed by carrying out calculations on fully optimized geometries of the ideal extended (Cs) conformation. Thus for $\mathrm{Gly}_{3}$ and $\mathrm{Gly}_{3}-M^{+}$complexes (complexation with $\mathrm{O} 13)$ geometry optimizations with $\left(180^{\circ}, 180^{\circ}\right.$, $180^{\circ}$ ) conformation led to cation affinities of $61.8,45.8$ and $34.4 \mathrm{kcalmol}^{-1}$ for $\mathrm{Li}^{+}, \mathrm{Na}^{+}$and $\mathrm{K}^{+}$, respectively, at MP2(FULL)/6-31G(d)//HF/6-31G(d). The relative binding affinities are within $1 \mathrm{kcal} \mathrm{mol}^{-1}$ of those obtained with POPT calculation (Table 2).

The metal ion affinities follow the order $\mathrm{Li}^{+}>\mathrm{Na}^{+}>\mathrm{K}^{+}$. This is evidently due to decrease in the stabilizing electrostatic interaction between the peptide and metal ion with decreasing charge density as a result of the increasing size of the cation. However, significant binding affinity is noted for heavier metal ions also in helical peptides. The binding energies of FOPT structures of helical peptides (computed using the single point energy of the peptide frozen at the complex geometry) show the same trends as described above, although the absolute affinities are overestimated.

Mass spectral discrimination of ion binding: Peptides in methanol $\left(1.0 \times 10^{-3} \mathrm{M}\right)$ were treated with $3.0 \times 10^{-3} \mathrm{M}$ solution of $\mathrm{Li}_{2} \mathrm{CO}_{3}$ in water; the time course of the lithium adduct formation was followed using ESIMS. The ratio of the intensities of the lithium and proton adducts increased with time and ESI mass spectra showed the presence of only the lithium adducts after $12 \mathrm{~h}$ of incubation. The complete absence of proton, sodium and potassium adducts which are normally observed under the ESI conditions indicates that the ionization due to metallation is mainly taking place in the solution state itself rather than in the gas phase. The noncovalent metal complex formed in the bulk solution is not destroyed under the mild ESI conditions used in this study. Detection of intact noncovalent complexes in the gas phase using mass spectrometry has been reported by several research groups. ${ }^{[5]}$ The single ion free energy of solvation of $\mathrm{Li}^{+}$in methanol has been estimated to be $-115 \mathrm{kcal} \mathrm{mol}^{-1} \cdot{ }^{[34]}$ This would imply that the free energy of lithium ion binding to the peptides and the additional solvation of the coordinated complex are sufficiently large in magnitude to overcome the solvation free energy of the metal ion in methanol.

To evaluate the relative binding efficiency of the alkali metal ions $\mathrm{Li}^{+}, \mathrm{Na}^{+}$, and $\mathrm{K}^{+}$with hydrophobic peptides, solutions of peptides in methanol $\left(1.0 \times 10^{-3} \mathrm{M}\right)$ were treated with a 1:1:1 equimolar mixture of $\mathrm{Li}_{2} \mathrm{CO}_{3}, \mathrm{Na}_{2} \mathrm{CO}_{3}$ and $\mathrm{K}_{2} \mathrm{CO}_{3}$ $\left(1.0 \times 10^{-3} \mathrm{M}\right)$ and incubated for $12 \mathrm{~h}$ at room temperature. ESI spectra were recorded using methanol as the mobile phase. Typical spectra for a helical (6) and a hairpin (17) peptide are shown in Figure 5. In Figure 5b, the intensities of the peaks corresponding to the metal adducts of peptide $\mathbf{1 7}$ are in the order lithium $(\mathrm{m} / \mathrm{z}, 931)>\operatorname{sodium}(\mathrm{m} / \mathrm{z}$ 947) $>$ potassium $(\mathrm{m} / \mathrm{z}$ 963). A similar trend is observed in the helical peptide also (Figure $5 \mathrm{a}$ ), which indicates that the binding efficiency is in the order $\mathrm{Li}^{+}>\mathrm{Na}^{+}>\mathrm{K}^{+}$. Evidently, the large binding affinities from chelation enable $\mathrm{Na}^{+}$and $\mathrm{K}^{+}$ions to overcome the free energies of solvation in methanol ( -92 and $-75 \mathrm{kcal} \mathrm{mol}^{-1}$, respectively). ${ }^{[34]}$ It is interesting that the order of binding affinities is reflected in the relative intensities of
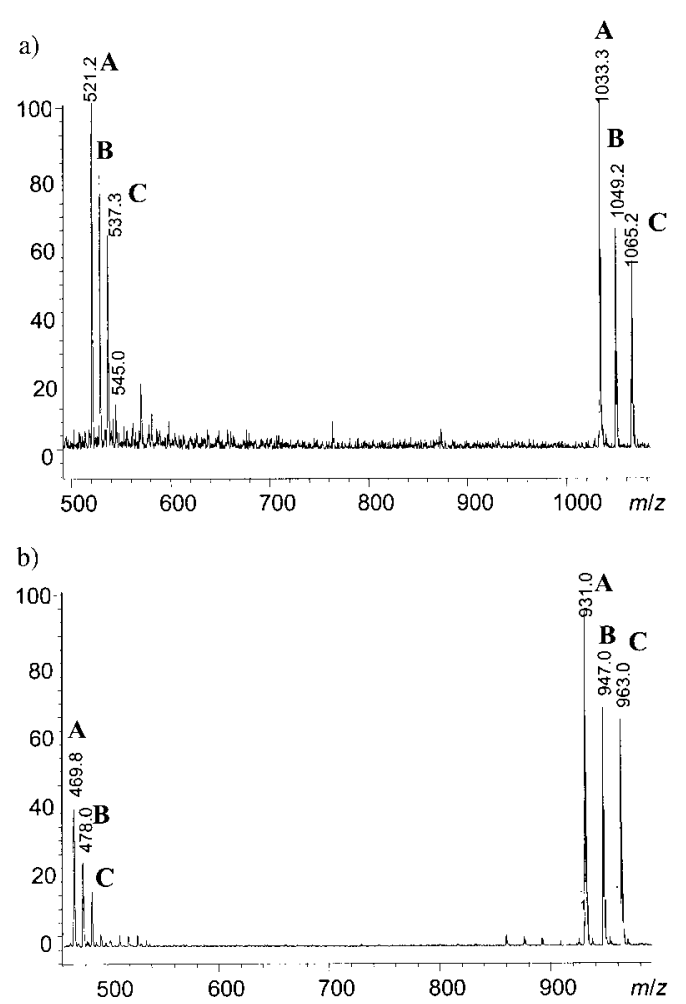

Figure 5. The competitive binding of $\mathrm{Li}^{+}, \mathrm{Na}^{+}, \mathrm{K}^{+}$to a) helical peptide $\mathbf{6}$, and b) hairpin peptide 17. $\mathbf{A}$ : lithium adduct, $\mathbf{B}$ : sodium adduct and $\mathbf{C}$ : potassium adduct. The binding affinity is in the order $\mathrm{Li}^{+}>\mathrm{Na}^{+}>\mathrm{K}^{+}$.

the adduct peaks in spite of the variable amount of solvation free energies for the cations.

Ab initio studies of protonation in $\mathbf{G l y}_{3}$ : Several possible sites of protonation were explored, while considering the amide carbonyl oxygen as well as ester oxygen atoms as proton acceptors. The possible sites of protonation at oxygen atoms are the formyl group [O13], Gly(2) CO [O15], Gly(3) $\mathrm{CO}[\mathrm{O} 16]$ and the ester methoxy oxygen (O9). Gly(1) CO was not investigated as its environment is very similar to that of Gly(2) CO. Table 3 gives a summary of the energetics of partially and fully optimized structures for a helical conformation protonated (at O15) and partially optimized structures for the $\beta$-strand protonated (O13 and O15) adducts.

Protonation at the carbonyl oxygen [O15] of the second Gly residue of the $3_{10}$-helical Gly $_{3}$ peptide (2a in Figure 6) leads to the highest proton affinity $\left(227.2 \mathrm{kcal} \mathrm{mol}^{-1}\right)$. The structure, in which the proton is attached to the $\mathrm{sp}^{3}$ oxygen of ester group (O9) forming a hydrogen bond with O14 (2 b in Figure 6), is also noted to be a stable geometry for the helical $\mathrm{Gly}_{3}$ complex. Interestingly even though the carbonyl oxygen $\left(\mathrm{O} 14, \mathrm{sp}^{2}\right.$ oxygen) has a greater affinity to get protonated, compared with $\mathrm{sp}^{3}$ oxygen (O9), protonation occurs at $\mathrm{O} 9$. Such a $\mathrm{C}_{10}$ cyclic structure is common in neutral peptides with the carbonyl oxygen forming a 10-membered cycle as a result of an intramolecular hydrogen bond with a suitably placed $\mathrm{N}-\mathrm{H}$ unit. This geometric pattern is responsible for the $\beta$-turn structural motif. ${ }^{[31]}$ The same kind of arrangement in the protonated complex suggests that the $[\mathrm{O}-\mathrm{H}]^{+}$group acts as a 
Table 3. Proton affinities $\left[\mathrm{kcalmol}^{-1}\right]$ of $\mathrm{CHO}-(\mathrm{Gly})_{2}-\mathrm{OCH}_{3}\left[\mathrm{Gly}_{2}\right]$ and CHO- $(\mathrm{Gly})_{3}-\mathrm{OCH}_{3}\left[\mathrm{Gly}_{3}\right]$ in helical and $\beta$-strand conformations.

\begin{tabular}{lcccc}
\hline Level of theory & \multicolumn{2}{c}{ Helical conformation } & \multicolumn{2}{c}{$\beta$-strand conformation } \\
& POPT $^{[a]}$ & FOPT $^{[\mathrm{d}]}$ & POPT $^{[\mathrm{b}]}$ & POPT $^{[\mathrm{c}]}$ \\
\hline $\mathrm{H}^{+}$affinity of $\mathrm{Gly}_{2}$ & & & & \\
$\mathrm{HF} / 6-31 \mathrm{G}(\mathrm{d})$ opt & 220.42 & 249.45 & 214.36 & 212.06 \\
B3LYP/6-31G(d) & 219.67 & 245.15 & 214.15 & 211.09 \\
MP2(full)/6-31G(d) & 216.29 & 238.92 & 210.79 & 207.23 \\
$\mathrm{H}^{+}$affinity of Gly & & & & \\
$\mathrm{HF} / 6-31 \mathrm{G}(\mathrm{d})$ opt & 230.52 & 256.79 & 215.27 & 212.41 \\
B3LYP/6-31G(d) & 229.93 & 251.59 & 215.61 & 211.18 \\
MP2(full)/6-31G(d) & 227.18 & 245.05 & 212.29 & 207.15
\end{tabular}

[a] Partial optimization at fixed dihedral angles $\left(\phi=-60^{\circ} ; \psi=-30^{\circ} ; \omega=\right.$ $180^{\circ} ; 3_{10}$-helical conformation); protonation occurs at middle oxygen (O15). [b] Partial optimization of $\beta$-strand conformation at fixed dihedral angles $\left(\phi=-120^{\circ} ; \psi=120^{\circ} ; \omega=180^{\circ}\right)$; protonation occurs at the terminal carbonyl oxygen (O10 for $\mathrm{Gly}_{2}$ and $\mathrm{O} 13$ for $\left.\mathrm{Gly}_{3}\right)$. [c] Partial optimization of $\beta$-strand conformation at fixed dihedral angles $\left(\phi=-120^{\circ} ; \psi=120^{\circ}\right.$; $\left.\omega=180^{\circ}\right)$; protonation occurs at the middle carbonyl oxygen (O15).[d] Full optimization of the complexes taking the POPT structures as initial guess. The energies of the free peptide were computed by a single point calculation taking the fully optimized geometry of the complex without the ions to calculate binding energies (affinities). The affinities are consequently overestimated.

surrogate NH unit. However, the proton affinity of this cyclic form is nearly $10 \mathrm{kcal} \mathrm{mol}^{-1}$ less stable than the most stable O15 protonated complex, 2a. This implies that bridging in the protonated helical form is not enough to overcome the inherently greater preference for carbonyl oxygen protonation. Full optimization of the partially optimized bridged structure $\mathbf{2 b}$ leads to $\mathbf{2 c}$. The helical motif is retained even after lifting the constraints. The ester carbonyl group is oriented towards the amide carbonyl oxygen, $\mathrm{O} 14$ to form the $\mathrm{C}=\mathrm{O} \cdots+\mathrm{H}-\mathrm{O}=\mathrm{C}$ ionic hydrogen bond. For the $\beta$-strand peptides (2d and $\mathbf{2 e}$ ) the proton binding to the formyl oxygen $\left(\mathrm{O} 13,212 \mathrm{kcal} \mathrm{mol}^{-1}\right)$ is favored as compared with binding to one of the middle oxygen atoms $\left(\mathrm{O} 15,207 \mathrm{kcal} \mathrm{mol}^{-1}\right)$. This feature has also been noted for metallation.

Gly $_{2}$ complexes: In order to examine the generality of the modes of metallation/protonation, we also carried out calculations on a simpler system $\mathrm{CHO}-\mathrm{Gly}_{2}-\mathrm{OCH}_{3}\left(\mathrm{Gly}_{2}\right)$. The results obtained for the metallation of $\mathrm{Gly}_{2}$ exactly parallel those of $\mathrm{Gly}_{3}$ metallation [data not shown]. Proton affinities of $\mathrm{Gly}_{2}$ in the helical (type III $\beta$-turn) and $\beta$-strand conformation are given in Table 3. Full geometry optimization (FOPT) of helical $\mathrm{Gly}_{2}-\mathrm{H}^{+}$from partially optimized structures leads to four minima, $\mathbf{3 a}, \mathbf{3 b}, \mathbf{3 c}$ and $\mathbf{3 d}$ (Figure 7). The most stable complex, $\mathbf{3} \mathbf{a}$ is a $\mathrm{C}_{7}$ cyclic structure in which the proton attached to $\mathrm{O} 15$ forms a strong hydrogen bond with the ester carbonyl oxygen. This is similar to the gas phase equilibrium geometry, the $\mathrm{C}_{7}$ cyclic structure, reported at a high level of theory for dipeptides where N-H group forms a hydrogen bond with the suitably oriented carbonyl oxygen. ${ }^{[12 d]}$ The proton attached to the middle carbonyl oxygen plays the role of the amide proton to stabilize this cyclic form. Another $\mathrm{C}_{7}$ structure $\mathbf{3 b}$ is also noted where the bridging occurs with formyl carbonyl oxygen and it is $2.0 \mathrm{kcal} \mathrm{mol}^{-1}$ higher in energy than $3 \mathbf{a}$. The two other minima are $\mathrm{C}_{10}$ cyclic structures $\mathbf{3 c}$ and $\mathbf{3 d}$. The cyclic form $\mathbf{3 c}$, in which the ester carbonyl is protonated and forms a strong hydrogen bond with the formyl carbonyl oxygen, is a mere $2.0 \mathrm{kcalmol}^{-1}$ higher in energy than the most stable $\mathrm{C}_{7}$ cyclic form 3a. Another $\mathrm{C}_{10}$ cyclic form, $\mathbf{3 d}$, is obtained as a local minimum where the $\mathrm{sp}^{3}$ oxygen

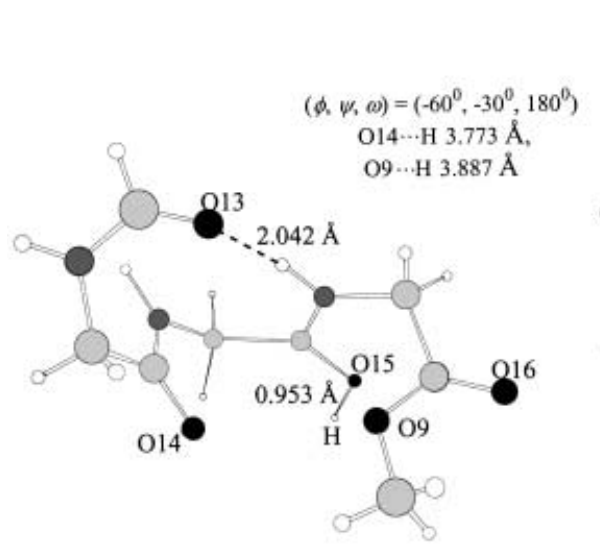

2a

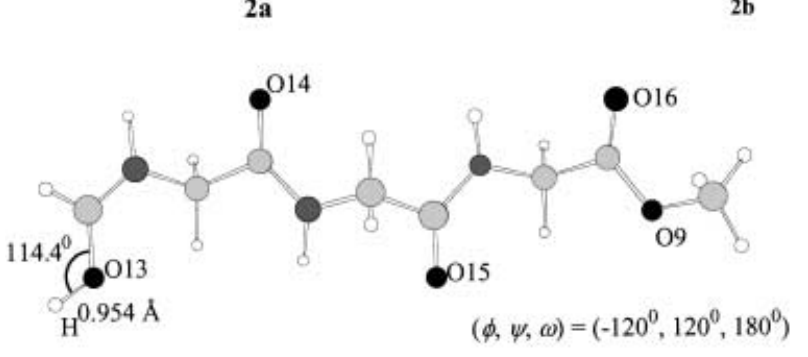

2d

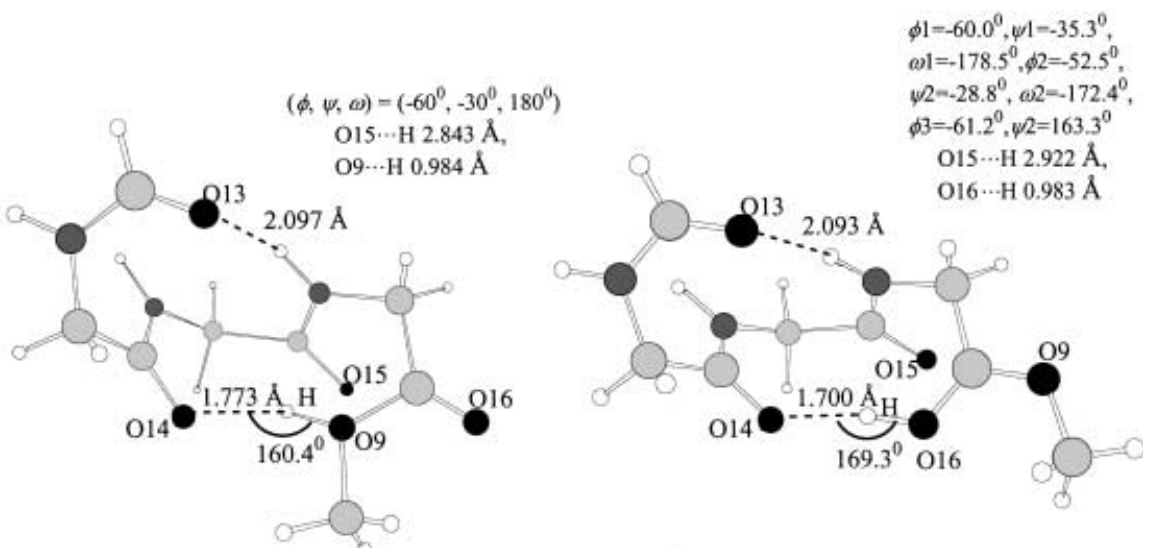

$2 c$

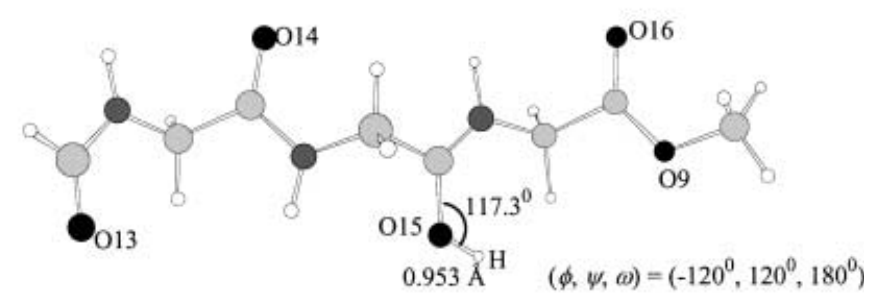

2 e

Figure 6. HF/6-31G(d) partially optimized geometries of protonated $\mathrm{Gly}_{3}$ in $3_{10}$-helical (2a and $\mathbf{2}$ b), $\beta$-strand (2 d and $\mathbf{2}$ e) conformations and fully optimized geometry of helical conformation $(\mathbf{2} \mathbf{c})$ taking $\mathbf{2} \mathbf{b}$ as starting point. 
of the terminal ester group is protonated and bridges with the carbonyl oxygen. However, this geometry is at a higher energy on the potential energy surface $\left(16 \mathrm{kcal} \mathrm{mol}^{-1}\right.$ higher in energy than the most stable form $3 \mathbf{a}$ ). This is apparently because of the lower proton affinity of the $\mathrm{sp}^{3}$ oxygen compared with $\mathrm{sp}^{2}$ oxygen. These stabilized complexes (3a and $\mathbf{3 d}$ )are quite interesting for the fact that the optimized geometry exhibits a " $\beta$-turn like" structural motif. The presence of the ionic hydrogen bond $\left(\mathrm{C}=\mathrm{O}-\mathrm{H}^{+} \ldots \mathrm{O}\right)$, which has been shown to be stronger ${ }^{[35]}$ compared with neutral hydrogen bond (N-H... $\mathrm{O}=\mathrm{C}$ ), may favor this structure to a greater extent. Very short hydrogen bond distances are noted for all of the bridged structures (Figure 7), which is strongly suggestive of the formation of a highly stable cyclic hydrogen bonded form in the proton adduct.

Fragmentation studies on the hydrophobic peptides under the ESIMS conditions: The fragmentation of protonated peptides is charge directed, requiring proton localization at the cleavage sites. ${ }^{[36]}$ Fragmentation patterns observed during the collision induced dissociation of protonated peptides have been used to predict the site of protonation. ${ }^{[37]}$ The commonly observed fragmentation patterns and the nomenclature used for the fragmentation of peptides are shown in Scheme 2.

Wysocki et al. have shown that peptides with no basic residues undergo fragmentation more easily at a given collision energy than peptides containing a basic residue. In hydrophobic peptides, the bound proton is not strongly localized as in the cases of peptides having a basic side chain. Hence, less energy is required for "proton mobilization" ${ }^{[38]}$ It has been shown by MNDO and ab initio calculations that when the proton is located on the carbonyl oxygen, the bond order of the amide bond is significantly greater relative to that

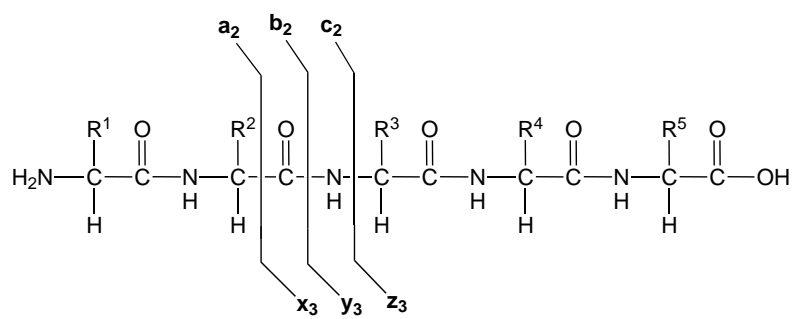

Scheme 2. Fragmentation pattern observed in peptides.

of the unprotonated neutral amide group; this in turn hinders cleavage at the amide bond. In contrast, when the proton is located on the amide nitrogen, the amide bond order is significantly smaller than the neutral amide and therefore this appears as a possible fragmenting structure, leading to the formation of $\mathbf{b}$ and $\mathbf{y}$ type ions. ${ }^{[39]}$ So, regardless of the initial protonation site, a proton is transferred to a less basic amide nitrogen by ion activation facilitating the fragmentation. The initially formed state could be a thermally stable form. Due to the thermal excitation occurring at the electrospray capillary and the collisional activation in the capillary skimmer region, it is possible that rapid proton exchange takes place along the peptide backbone to give a heterogeneous population of protonated species. The order of energy requirement for fragmentation of peptides depends on the initial site of protonation. Experimental studies reveal the energy required for fragmentation depends on the protonation site, following the order arginine $>$ lysine $>\mathrm{N}$-terminus $>$ amide carbonyl $>$ amide NH. ${ }^{[38]}$

Fragmentation of the hydrophobic peptides used in our study was achieved at a skimmer potential of $100 \mathrm{~V}$. Increas-

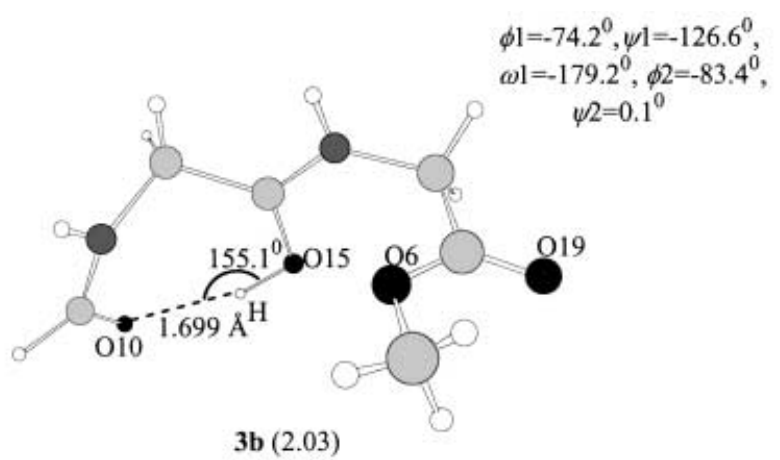

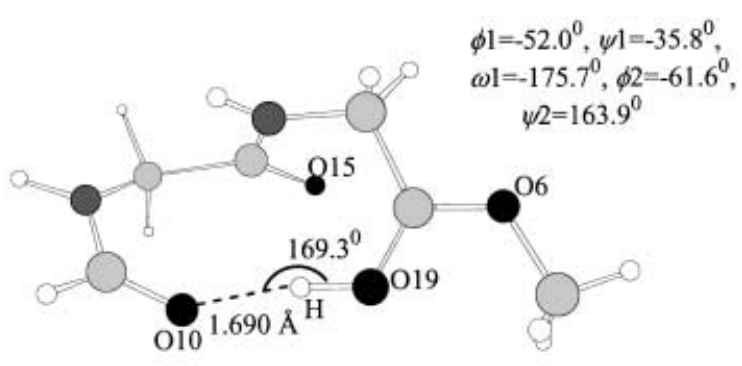

3 e (1.99)

$$
\begin{gathered}
\phi 1=-72.0^{0}, \psi 1=-22.0^{0}, \\
\omega 1=-164.4^{0}, \phi 2=59.2^{0}, \\
\psi 2=147.8^{0}
\end{gathered}
$$

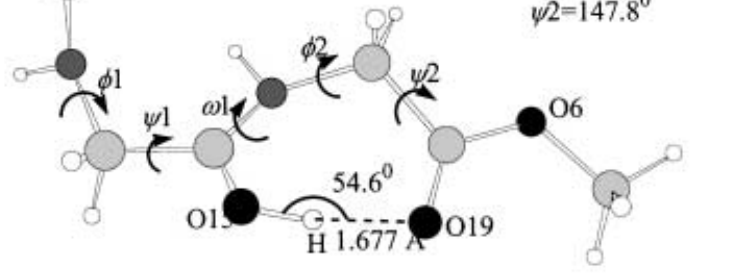

3a $(0.00)$

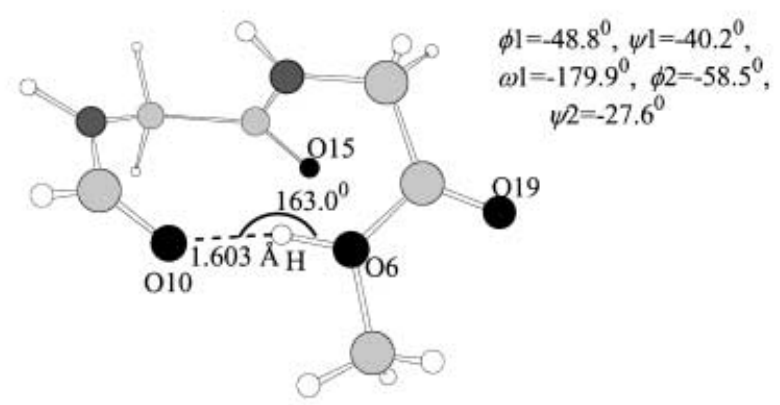

3d (16.01)

Figure 7. HF/6-31G(d)Fully optimized geometries of protonated complexes of $\mathrm{Gly}_{2}$ in $\mathrm{C}_{7}$ conformation $(\mathbf{3 a}$ and $\mathbf{3 b})$ and $\mathrm{C}_{10}$-conformation $(\mathbf{3} \mathbf{c}$ and $\mathbf{3 d})$. Relative energies at MP2(full)/6-31G(d)//HF/6-31G(d) are given in $\mathrm{kcal} \mathrm{mol}^{-1}$ in the parentheses. 
ing the skimmer potential results in increased acceleration of the ions. Increase in internal energy of the ions during the collisions with the collision gas (nitrogen) results in fragmentation of the peptides. Proton mobilisation from the carbonyl oxygen to the amide nitrogen under the electrospray conditions with a skimmer potential of $100 \mathrm{~V}$ could be responsible for the fragmentation observed. A typical example of the low energy collision induced fragmentation of a helical peptide $\mathbf{3}$ is shown in Figure 8.

The initial fragmentation results in the formation of fragments at $\mathrm{m} / \mathrm{z} 639.5,568.4$ and 469.3 corresponding to the fragments $\mathbf{b}_{\mathbf{4}}, \mathbf{b}_{5}$ and $\mathbf{b}_{6}$. This indicates that the fragmentation proceeds from the cleavage at the amide bonds of C-terminal residues. Charge directed fragmentation of peptides with charged residues under collision induced dissociation has been reported. ${ }^{[39,40]}$ The observation of a single series of $\mathbf{b}$ type ions due to the cleavage of the C-terminal residues indicates that the charged site in the peptide could be in the vicinity of the C-terminus. Dissociation pathways of alkali-cationized peptides have been studied using multiple stages of mass spectrometry by Lin et al. They have shown the successive dissociation of the residues from the C-terminus of alkalicationized peptides. ${ }^{[41]}$ In the case of the $\beta$-hairpin peptide $\mathbf{1 7}$, an increase in skimmer potential to $100 \mathrm{~V}$ leads to the appearance of peaks at $m / z$ 792.8, 693.7, 611.7 and 512.5, corresponding to the fragments $\mathbf{b}_{7}, \mathbf{b}_{6}, \mathbf{y}_{6}$ and $\mathbf{y}_{5}$. Formation of these fragments indicates the cleavage of amide bonds from both the $\mathrm{C}$-terminal and $\mathrm{N}$-terminal residues. Interestingly in peptide 17, cleavage at the [X-Pro bond] "Pro" residue is not observed despite the reported higher proton affinity, which normally results in higher fragmentation at this residue. ${ }^{[42]}$ This observation may be a consequence of the rigid $\beta$-turn conformation, which results in the carbonyl of the amide being inaccessible to protonation. In both cases, further increase in the skimmer potential results in the formation of fragments due to random cleavage. The fragmentation pattern of the two peptides suggests that the protonation is more homogeneous in helices as compared to $\beta$-hairpins. Hence, fragmentation of helices implies a single cleavage pattern, while hairpin peptides undergo cleavage simultaneously at different sites. These observations support the view that in peptide helices protonation/metallation is more favoured at the C-terminal end, a feature discussed in the preceding sections.

The effects of increasing the skimmer potential on the ESI mass spectra of peptides under conditions where both protonated and metallated species occur were studied. Figures 9 and 10 illustrate the results obtained for the model helical peptide 3 and $\beta$-hairpin peptide 17. The relative intensity of the protonated species decreases for peptides which exist as a mixture of the protonated and metallated species (Figures 9a, 10a), while that of the metallated peak increases on increasing the skimmer potential (Figures $9 b$, $10 \mathrm{~b})$. This suggests that fragmentation from the protonated species is preferred, which in turn may be a reflection of the difference in the nature of the binding of the proton and metal ion to the peptide. The alkali metal ion can coordinate with more than one carbonyl group forming a chelate, while the protons predominantly bind to a single amide carbonyl. Coordination of alkali metal ions or a proton to the amide oxygen leads to a partial double bond character in the $\mathrm{CO}-\mathrm{NH}$ bond, ${ }^{[43]}$ while coordination to the nitrogen reduces the bond order of the amide bond. ${ }^{[39]}$ It has been shown experimentally that the binding energy of lithium to amides is higher compared with amines, while amines have higher proton affinity than amides. ${ }^{[44]}$ Under the low energy collision induced activation conditions the transfer of protons from the amide carbonyl to the nitrogen is possible, while the transfer
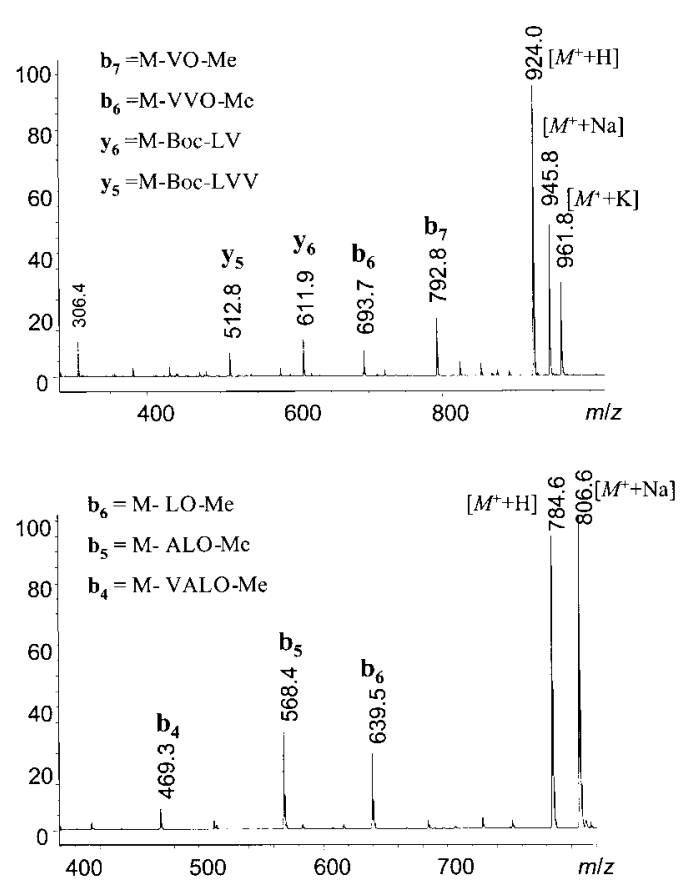
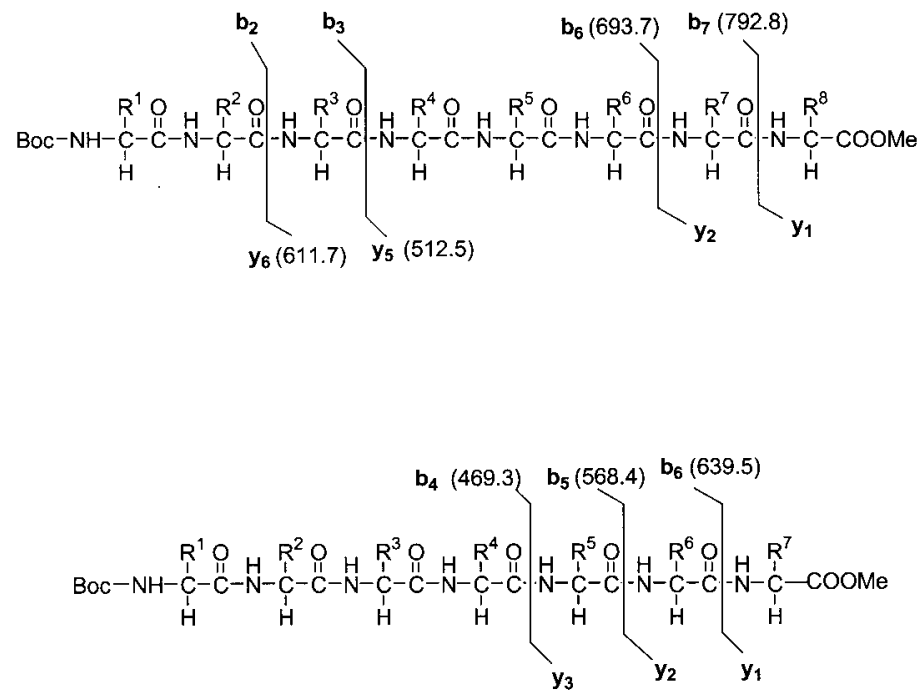

Figure 8. The initial fragmentation pattern observed in a hairpin peptide $\mathbf{1 7}$ (top) and a helical peptide $\mathbf{3}$ (bottom). The spectra were recorded at skimmer potential $100 \mathrm{~V}$. 

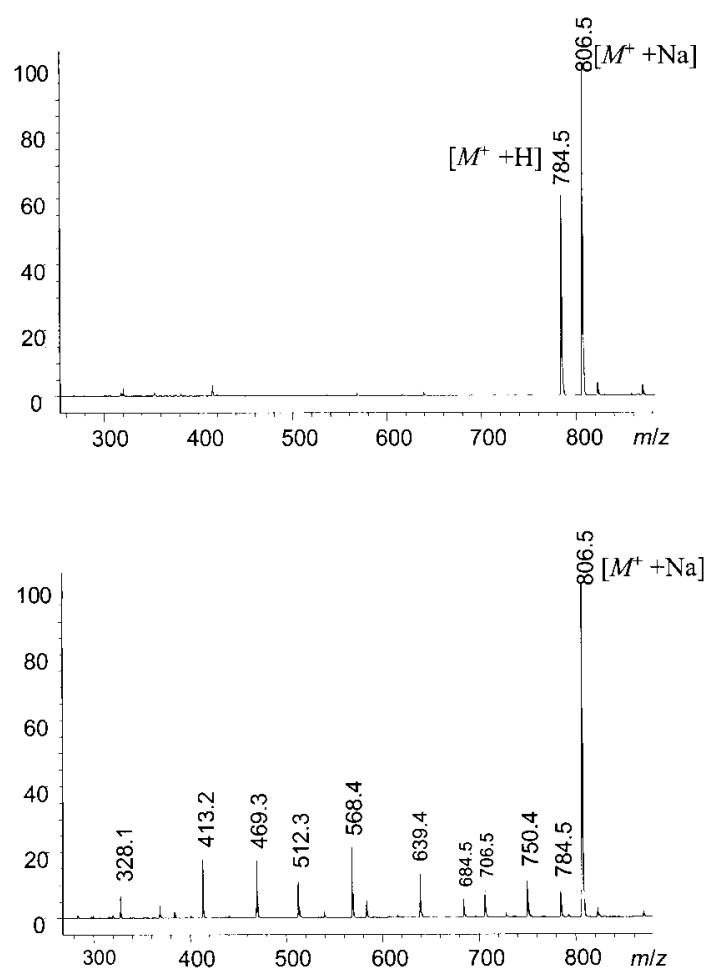

Figure 9. Fragmentation of proton and metal adducts of peptide 3. The ESIMS spectra were recorded in methanol at skimmer potential $20 \mathrm{~V}$ (top) and at $200 \mathrm{~V}$ (bottom). The proton adduct is fragmented completely while the metal adduct is stable at $200 \mathrm{~V}$ indicating that the fragmentation proceeds from the proton adduct.
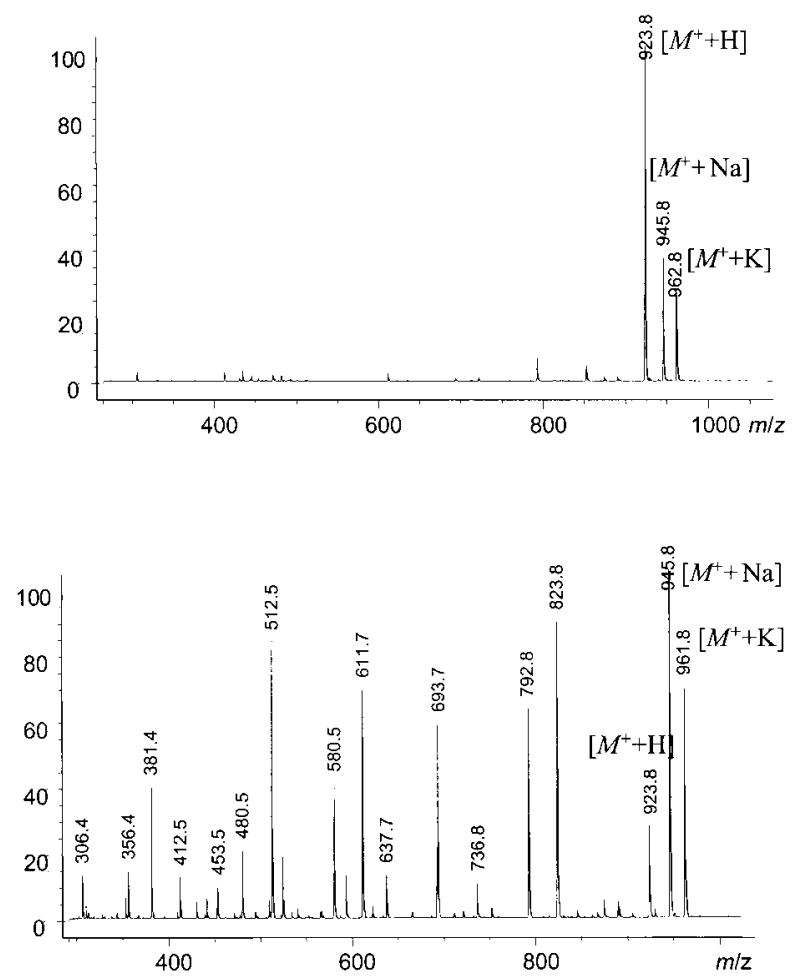

Figure 10. Fragmentation of proton and metal adducts of peptide 17. The ESIMS spectra were recorded in methanol at skimmer potential $20 \mathrm{~V}$ (top) and at $200 \mathrm{~V}$ (bottom). As in the case of helical peptide, the proton adduct undergoes fragmentation faster than the metal adducts. of the metal ion from the amide carbonyl to the nitrogen appears to be much less facile. Hence in a mixture of peptides with the protonated and metallated species, the fragmentation proceeds from the protonated species more readily than the metallated species.

\section{Conclusion}

Under electrospray ionization mass spectrometry conditions completely hydrophobic peptides ionize surprisingly well, yielding both protonated and metallated species. Studies on peptides with structurally well defined conformations in solutions lead to the following conclusions.

1) Hydrophobic peptides up to a length of 10 residues show only singly charged states. Helices of length greater than 10 residues also show doubly charged states with the relative intensity increasing with helix length. Doubly charged states are observed as major species (or the only species) in helices, where the continuous chain of intramolecular hydrogen bonds is interrupted by insertion of a Pro residue or by reversal of chirality. The observed protonation/ metallation of helical peptides is consistent with the maintenance of the conformational states in solution, during ion formation under electrospray conditions.

2) The favoured site of protonation/metallation in peptide helices is the C-terminus, ${ }^{[45]}$ which contains multiple CO groups favourably oriented for chelating a cation.

3) Ab initio calculations on the model peptide $\mathrm{N}$-formyltriglycine methyl ester constrained to a conformation corresponding to a single helical turn reveal that tridentate coordination involving the three $\mathrm{C}$-terminus $\mathrm{CO}$ groups is energetically favourable for $\mathrm{Li}^{+}, \mathrm{Na}^{+}$and $\mathrm{K}^{+}$. For $\mathrm{H}^{+}$, coordination to two $\mathrm{CO}$ groups is preferred.

4) Ab initio calculations also establish that the protonation/ metallation sites in extended sheet-like conformation are heterogeneous with coordination favoured at isolated $\mathrm{CO}$ groups.

5) In the case of both helices and hairpins, binding energies of alkali metals follows the order $\mathrm{Li}^{+}>\mathrm{Na}^{+}>\mathrm{K}^{+}$.

6) Collision induced fragmentation patterns provide insight into the sites of protonation. For peptide helices fragmentation occurs almost exclusively from the C-terminal end of the molecule, whereas for hairpins fragmentation proceeds by multiple pathways indicative of heterogeneity of protonation sites, as also indicated by theoretical calculations.

7) Fragmentation of protonated species occurs preferentially in the presence of a mixture of both protonated and metallated species, providing evidence for facile movement of protons from the carbonyl group to the amide nitrogen under ESI conditions.

The present studies reveal that both peptide chain length and conformation determine sites of protonation/metallation and also have a controlling influence on fragmentation patterns.

\section{Experimental Section}

All peptides used in this study $\mathbf{1 - 1 9}$ except for peptides $\mathbf{1 4}$ and $\mathbf{1 5}$ were synthesized using conventional solution-phase methods. The structures of 
the peptides were characterized in solution and in the solid state using NMR and crystallographic techniques ${ }^{[13-25]}$ (Table 1). Antiamoebin (14) and zervamicin (15) were obtained from fungal cultures and characterized as described earlier. ${ }^{[21,22]}$ For metal-binding experiments, solutions of peptides in methanol $\left(1.0 \times 10^{-3} \mathrm{M}\right)$ were incubated with 3 molar equivalence of metal salt solution in water $\left(3.0 \times 10^{-3} \mathrm{M}\right)$ for $12 \mathrm{~h}$ at room temperature. The mixtures were diluted 20 times with methanol and $5 \mu \mathrm{L}$ of the diluted mixture was injected into the mass spectrometer. To investigate the competitive binding of $\mathrm{Li}^{+}, \mathrm{Na}^{+}$and $\mathrm{K}^{+}$to hydrophobic peptides, the peptides in methanol $\left(1.0 \times 10^{-3} \mathrm{M}\right)$ were mixed with a $1: 1: 1$ equimolar mixture of $\mathrm{Li}_{2} \mathrm{CO}_{3}, \mathrm{Na}_{2} \mathrm{CO}_{3}$ and $\mathrm{K}_{2} \mathrm{CO}_{3}\left(1.0 \times 10^{-3} \mathrm{M}\right)$ in pure water from a MilliQ apparatus (Millipore Inc.) with a conductance of $18.2 \mathrm{~m} \Omega$ and incubated for $12 \mathrm{~h}$ at room temperature. The solutions were diluted 20 times with methanol prior to injection into the mass spectrometer.

All the ESIMS experiments were carried out on a Hewlett-Packard (model HP-1100) electrospray mass spectrometer. ${ }^{[5 e, f]}$ Methanol at a flow rate of $30 \mu \mathrm{Lmin}^{-1}$ was used as the mobile phase for the ESIMS. A volume of $5 \mu \mathrm{L}$ of the peptide solution in methanol $5.0 \times 10^{-5} \mathrm{M}(250$ picomoles of the peptide) was used for each experiment. Electrospray was carried out using pneumatic assistance with nitrogen gas. The capillary tip was held at $4000 \mathrm{~V}$. The spectra were recorded in the positive ion detection mode. The spray chamber used a nitrogen gas at a flow rate of $10 \mathrm{Lmin}^{-1}$ at $150{ }^{\circ} \mathrm{C}$. The instrument has two variable skimmers. Skimmer 2 was held constant at $10 \mathrm{~V}$ and skimmer 1 was held at $30 \mathrm{~V}(\Delta V=20 \mathrm{~V})$. For the fragmentation experiments, the skimmer potential $\Delta V$ was gradually increased from 20 to $200 \mathrm{~V}$. Data was acquired across the mass range of $m / z 100-3000$ with a quadrupole cycle time of $3 \mathrm{~s}$. The spectrometer was calibrated using five calibration standards provided by the manufacturer. Data processing was done using HP Chemstation software. The charge states were determined using the isotopic peaks.

Computational details: The model peptides and their complexes with $\mathrm{H}^{+}$, $\mathrm{Li}^{+}, \mathrm{Na}^{+}$and $\mathrm{K}^{+}$were optimized at the HF/6-31G(d) level. Two different conformations were considered: $3_{10}$-helical and $\beta$-strand. In each case, all the geometric parameters were optimized, except the peptide torsional angles $\phi, \psi$ and $\omega$ characteristic of these conformations. The $(\phi, \psi, \omega)$ constraints imposed are $\left(-60^{\circ},-30^{\circ}, 180^{\circ}\right)$ and $\left(-120^{\circ}, 120^{\circ}, 180^{\circ}\right)$, respectively, for $3_{10}$-helical and $\beta$-strand peptides. Different sites of protonation and metallation were examined. The binding affinities were computed at B3LYP, and MP2 (FULL) levels, respectively, at 6-31G(d) basis set using the HF/6-31G(d) geometry.

Full geometry optimizations (lifting the constraints imposed on $\phi, \psi$ and $\omega$ dihedral angles) of all the complexes were also carried out at the HF/6$31 \mathrm{G}(\mathrm{d})$ level taking the corresponding partially optimized geometry of the complex. Single-point energies were computed at B3LYP, and MP2(full) levels. Vibrational frequency analyses of all the fully optimized geometry of the complexes were carried out to confirm that they were true minima. All the calculations were done using the Gaussian suite of programs. ${ }^{[46]}$

\section{Acknowledgements}

The mass spectrometry facility was supported by a program grant in the area of "Drug and Molecular Design" by the Department of Biotechnology, Government of India.

[1] a) J. Fenn, M. Mann, C. K. Meng, S. F. Wong, C. M. Whitehouse, Science 1989, 246, 64; b) M. Karas, P. Hillenkamp, Anal. Chem. 1988, 60, 2299; c) R. C. Beavis, B. T. Chait, Proc. Natl. Acad. Sci. USA 1990, 87,6873 ; d) B. T. Chait, S. B. H. Kent, Science 1992, 257, 1885; e) G. Siuzdak, Proc. Natl. Acad. Sci. USA 1994, 91, 11290; f) S. D. Fuerstenau, W. H. Benner, J. J. Thomas, C. Brugidou, B. Bothner, G. Siuzadak, Angew Chem. 2001, 113, 559; Angew Chem. Int. Ed. 2001, $40,541$.

[2] a) S. K. Choudbury, V. Kata, B. T. Chait, J. Am. Chem. Soc. 1990, 112, 992; b) F. Wang, X. Tang, Biochemistry 1996, 35, 4069; c) J. B. Fenn, J. Am. Soc. Mass Spectrom. 1993, 4, 524; d) C. S. Hoaglund-Hyzer, A. E. Counterman, D. E. Clemmer, Chem. Rev. 1999, 99, 3037.

[3] a) I. A. Kaltashow, C. Fenselau, Proteins Struct. Funct. Genet. 1998, 27, 165 ; b) A. Li, C. Fenselau, I. A. Kaltashow, Proteins Struct. Funct.
Genet. Suppl. 2 1998, 22; c) D. Suckau, Y. Shi, S. C. Beu, M. W. Senko, J. P. Quinn, F. M. Wampler, F. W. McLafferty, Proc. Natl. Acad. Sci. USA 1993, 90, 790; d) R. R. Hudgins, M. A. Ratner, M. F. Jarrold, J. Am. Chem. Soc. 1998, 120, 12974; e) R. R. Hudgins, M. F. Jarrold, J. Am. Chem. Soc. 1999, 121, 3494; f) B. A. Collings, D. J. Douglas, J. Am. Chem. Soc. 1996, 118, 4488; g) P. A. Sullivan, J. Axelsson, S. Altmann, A. P. Quist, B. U. R. Sundqvist, C. T. Reimann, J. Am. Soc. Mass. Spectrom. 1996, 7, 329; h) D. E. Clemmer, R. R. Hudgins, M. F. Jarrold, J. Am. Chem. Soc. 1995, 117, 10141; i) S. J. Valentine, J. G. Anderson, A. D. Ellington, D. E. Clemmer, J. Phys. Chem. B 1997, 101, 3891; j) D. S. Gross, P. D. Schnier, S. E. Rodriguez-Cruz, C. K. Fagerquist, E. R. Williams, Proc. Natl. Acad. Sci. USA 1996, 93, 3143.

[4] a) L. M. Teesch, R. C. Orlando, J. Adams, J. Am. Chem. Soc. 1991, 113 3668; b) R. M. Pope, N. Shen, S. A. Hofstadler, D. V. Dearden, Int. J. Mass Spectrom. Ion Processes 1998, 175, 179.

[5] a) J. Loo, Mass Spectrom. Rev. 1997, 16, 1; b) R. Winston, M. C. Fitzgerald, Mass Spectrom Rev. 1997, 16, 165; c) M. Przybylski, M. O. Glocker, Angew. Chem. 1996, 108, 879; Angew. Chem. Int. Ed. Engl. 1996, 35, 806; d) R. D. Smith, Z. Zhang, Mass Spectrom. Rev. 1994, 13 411; e) S. S. Ray, P. Balaram J. Phys.Chem. B 1999, 103, 7068; f) S. S. Ray, S. K. Singh, P. Balaram, J. Am. Soc. Mass Spectrom. 2001, 12, 428.

[6] a) S. A. Carr, M. E. Hemling, M. F. Bean, G. D. Roberts, Anal. Chem. 1991, 63, 2802; b) C. E. Costello, Curr. Opin. in Biotech. 1999, 10, 22 c) K. Biemann, H. A. Scoble, Science 1987, 237, 992; c) D. F. Hunt, J. R. Yates III, J. Sharanowitz, S. Winston, C. R. Hauer, Proc. Natl. Acad. Sci. USA 1986, 83, 6233.

[7] a) A. Miranker, C. V. Robinson, S. E. Radford, R. T. Aplin, C. M. Dobson, Science 1993, 262, 896; b) M. Bouchard, D. R. Benjamin, P. Tito, C. V. Robinson, C. M. Dobson, Biophys. J. 2000, 78, 1010; c) D. E. Clemmer, M. F. Jarrold, J. Mass Spectrom. 1997, 32, 577 d) M. F. Jarrold, Annu. Rev. Phys. Chem. 2000, 51, 179; e) D. L. Smith, Y. Deng, Z. Zhang, J. Mass Spectrom. 1997, 32, 135; f) A. S. Danell, G. L. Glish, J. Am. Soc. Mass Spectrom. 2001, 12, 1331.

[8] a) D. R. Mueller, M. Eckerseley, W. Richter, J. Org. Mass. Spectrom. 1988, 23, 217; b) P. T. Kenney, K. Nomoto, R. Orlando, Rapid Commun. Mass Spectrom. 1992, 6, 95; c) R. S. Johnson, D. Krylov, K. A. Walsh, J. Mass Spectrom. 1995, 30, 386.

[9] a) P. A. Schindler, V. Dorsselaer, A. M. Falick, Anal. Biochem. 1993 , 213, 256; b) J. A. Demmers, J. Haverkamp, A. J. Heck, R. E. Koeppe II, J. A. Killian, Proc. Natl. Acad. Sci. USA 2000, 28, 3189.

[10] a) D. R. Barmidge, E. A. Dratz, A. J. Jesaitis, J. Sunner, Anal. Biochem. 1999, 269, 1.

[11] a) P. Balaram, J. Peptide Res. 1999, 54, 195; b) R. Kaul, P. Balaram, Bioorg. Med. Chem. 1999, 7, 105.

[12] a) S. Hoyau, K. Norrman, T. B. McMahon, G. Ohanessian, J. Am. Chem. Soc. 1999, 121, 8864; b) W. Y. Feng, S. Gronert, C. B. Lebrilla, J. Am. Chem. Soc. 1999, 121, 1365; c) J. Wu, C. B. Lebrilla, J. Am. Chem. Soc. 1993, 115, 3270; d) B. A. Cerda, S. Hoyau, G. Ohanessian, C. Wesdemiotis, J. Am. Chem. Soc. 1998, 120, 2437; e) K. Zhang, D. M. Zimmerman, A. Chung-Phillips, C. J. Cassady, J. Am. Chem. Soc. 1993 , 115, 10812; f) S. Hoyau, G. Ohanessian, Chem. Eur. J. 1998, 4, 1561.

[13] I. L. Karle, J. L. Flippen-Anderson, K. Uma, H. Balaram, P. Balaram, Biopolymers 1990, 29, 1433.

[14] I. L. Karle, J. L. Flippen-Anderson, K. Uma, P. Balaram, Proteins Struct. Funct. Genet. 1990, 7, 62.

[15] K. Uma, Molecular design of synthetic protein mimics: Construction of helices, Ph.D. Thesis, Indian Institute of Science, Bangalore (India), 1992.

[16] I. L. Karle, J. L. Flippen-Anderson, K. Uma, P. Balaram, Proc. Natl. Acad. Sci. USA 1998, 85, 299.

[17] I. L. Karle, J. L. Flippen-Anderson, K. Uma, P. Balaram, J. Pept. Protein Res. 1994, 44, 491.

[18] A. Banerjee, S. R. Raghothama, I. L. Karle, P. Balaram, Biopolymers 1996, 39, 279.

[19] I. L. Karle, J. L. Flippen-Anderson, K. Uma, M. Sukumar, P. Balaram, J. Am. Chem. Soc. 1990, 112, 9350.

[20] I. L. Karle, J. L. Flippen-Anderson, M. Sukumar, K. Uma, P. Balaram, J. Am. Chem. Soc. 1991, 113, 3592.

[21] I. L. Karle, M. A. Perozzo, V. K. Mishra, P. Balaram, Proc. Natl. Acad. Sci. USA. 1998, 90, 5501.

[22] I. L. Karle, J. L. Flippen-Anderson, S. Agarwalla, P. Balaram, Proc. Natl. Acad. Sci. 1991, 88, 5307. 
[23] C. Zhao, P. L. Polavarapu, C. Das, P. Balaram, J. Am. Chem. Soc. 2000, $122,8034$.

[24] I. L. Karle, C. Das, P. Balaram, Proc. Natl. Acad. Sci. USA 2000, 97, 3034.

[25] C. Das, G. A. Naganagowda, I. L. Karle, P. Balaram, Biopolymers 2001, 58,465 .

[26] a) Z. Wu, C. Fenselau, Tetrahedron 1993, 49, 9197; b) J. Wu, C. B. Lebrilla, J. Am. Chem. Soc. 1993, 115, 3270; c) K. Zhang, C. J. Cassady, A. Chung-Phillips, J. Am. Chem. Soc. 1994, 116, 11512.

[27] H. Nair, V. H. Wysocki, Int. J. Mass Spectrom. Ion Processes 1998, 174, 95.

[28] P. Chakrabarti, Biochemistry 1990, 29, 651.

[29] W. G. Hol, Prog. Biophys. Mol. Biol. 1985, 45, 149.

[30] a) I. L. Karle, P. Balaram, Biochemistry, 1990, 29, 6747; b) B. V. V. Prasad, P. Balaram, CRC Crit. Rev. Biochem. 1984, 16, 307; c) C. Toniolo, E. Benedetti, Trends Biochem. Sci. 1991, 16, 350.

[31] a) C. M. Venkatachalam, Biopolymers 1968, 6, 1425; b) G. D. Rose, L. M. Gierasch, J. A. Smith, Adv. Prot. Chem. 1985, 37, 1.

[32] a) R. F. Frey, J. Coffin, S. Q. Newton, M. Ramek, V. K. W. Cheng, F. A. Momany, L. Schafer, J. Am. Chem. Soc. 1992, 114, 5369; b) T. HeadGordon, M. Head-Gordon, M. J. Frisch, C. L. Brooks, J. A. Pople, J. Am. Chem. Soc. 1991, 113, 5989; c) H. S. Shang, T. Head-Gordon, J. Am. Chem. Soc. 1994, 116, 1528; d) M. Elstner, K. J. Jalkanen, M. Knapp-Mohammady, T. Frauenheim, S. Suhai, Chem. Phys. 2001, 263, 203; e) M. Elstner, K. J. Jalkanen, M. Knapp-Mohammady, T. Frauenheim, S. Suhai, Chem. Phys. 2000, 256, 15; f) R. A. Kubelka, G. D. Siva, T. A. Keiderling, J. Am. Chem. Soc. 2002, 124, 5325.

[33] J. S. Klassen, S. G. Anderson, A. T. Blades, P. Kebarle, J. Phys. Chem. 1996, $100,14218$.

[34] J. Burgess, Metal Ions in Solution, Ellis-Harwood, New York, 1978.

[35] a) M. Meot-Ner, J. Am. Chem. Soc. 1983, 105, 4906; b) J. Wu, E. Gard, J. Bregar, M. K. Green, C. B. Lebrilla, J. Am. Chem. Soc. 1995, 117, 9900.
[36] a) K. D. Ballard, S. J. Gaskell, Int. J. Mass Spectrom. Ion Processes 1991, 111, 171; b) A. J. Alexander, P. Thibault, R. K. Boyd, Rapid Commun. Mass Spectrom. 1989, 3, 30.

[37] L. Ashley, A. L. McCormack, A. Somogyi, V. H. Wysocki, Anal. Chem. 1993, 65, 2859.

[38] A. R. Dongre, J. L. Jones, A. Somogyi, V. H. Wysocki, J. Am. Chem. Soc. 1996, 118, 8365 .

[39] a) A. L. McCormack, A. Somogyi, A. R. Dongre, V. H. Wysocki, Anal. Chem. 1993, 65, 2859; b) A. Somogyi, V. H. Wysocki, I. Mayer, J. Am. Soc. Mass Spectrom. 1994, 5, 704.

[40] J. L. Jones, A. R. Dongre, A. Somogyi, V. H. Wyscocki, J. Am. Chem. Soc. 1994, 116, 8363.

[41] T. Lin, A. H. Payne, G. L. Glish, J. Am. Soc. Mass Spectrom. 2001, 12, 497.

[42] J. A. Loo, C. G. Edmonds, R. D. Smith, Anal. Chem. 1993, 65, 425.

[43] K. G. Rao, E. D. Backer, C. N. R. Rao, Chem. Commun. 1997, 350;

[44] W. Y. Feng, S. Gronert, C. B. Lebrilla, J. Am. Chem. Soc. 1999, 121, 1365.

[45] a) M. Kohtani, B. S. Kinnear, M. F. Jarrold, J. Am. Chem. Soc. 2000, 122, 12377; b) D. T. Kaleta, M. F. Jarrold, J. Phys. Chem. B 2001, 105 , 4436 ; c) B. S. Kinnear, M. R. Hartings, M. F. Jarrold, J. Am. Chem. Soc. 2002, 124, 4422.

[46] Gaussian 94, Revision C.2, M. J. Frisch, G. W. Trucks, H. B. Schlegel, P. M. W. Gill, B. G. Johnson, M. A. Robb, J. R. Cheeseman, T. Keith, G. A. Petersson, J. A. Montgomery, K.Raghavachari, M. A. AlLaham, V. G. Zakrzewski, J. V. Ortiz, J. B. Foresman, J. Cioslowski, B. B. Stefanov, A. Nanayakkara, M. Challacombe, C. Y. Peng, P. Y. Ayala, W. Chen, M. W. Wong, J. L. Andres, E. S. Replogle, R. Gomperts, R. L. Martin, D. J. Fox, J. S. Binkley, D. J. Defrees, J. Baker, J. P. Stewart, M. Head-Gordon, C. Gonzalez, J. A. Pople, Gaussian, Inc., Pittsburgh, PA (USA), 1995.

Received: March 26, 2002 Revised: June 6, 2002 [F3977] 